\title{
INSTRUÇÃO DE PERCURSO: DIMENSÕES ENSINÁVEIS PARA APRENDIZES OUVINTES DE LIBRAS (L2)
}

\section{ROUTE INSTRUCTION: TEACHABLE DIMENSIONS FOR HEARING LEARNERS OF LIBRAS (L2)}

\author{
Girlaine Felisberto de Caldas Aguiar* \\ Maria Augusta Reinaldo** \\ Shirley Barbosa das Neves Porto***
}

\begin{abstract}
Resumo: O ensino de Língua Brasileira de Sinais (Libras) para ouvintes numa perspectiva diferente das tradicionais aulas de vocabulário ou de gramática é o tema deste artigo, que tem por objetivos: (1) identificar as características definidoras do gênero instrução de percurso; e (2) apontar e descrever dimensões constitutivas desse gênero relevantes para o ensino de Libras como L2. Fundamentam o estudo pressupostos teóricos e metodológicos do interacionismo sociodiscursivo (ISD) para o ensino de língua centrado no gênero textual. Trata-se de uma pesquisa-ação e de caráter exploratório. Os resultados apontam duas dimensões relevantes para a construção do modelo didático desse gênero (MDG).

Palavras-chave: Ensino de Libras como L2. Interacionismo Sociodiscursivo. Gêneros textuais. Modelo didático de gênero.

Abstract: The teaching of Brazilian Sign Language (Libras) to listeners in a different perspective from the traditional vocabulary or grammar classes is the theme of this work, whose objectives are: 1) identify the defining characteristics of precursor instructions; 2) point out and describe the dimensions relevant to the teach of this genre. They are based on the study of the theoretical and methodological assumptions of sociodiscursive interactionism (ISD) for language teaching centered on textual genre. It is an action research, and an exploratory one. The initial results point to the need for insertion of this teaching model into the teacher training program of Libras.
\end{abstract}

Keywords: teaching of Libras as L2; sociodiscursive interactionism; textual genres; genre didactic model.

\section{Introdução}

Um breve histórico da descrição da Libras mostra que já há um amplo conhecimento de que a língua de sinais é uma língua natural, utilizada pelas comunidades surdas. De acordo com Quadros \& Karnopp (2004), a diferença básica entre língua de sinais e língua oral diz respeito à modalidade de apreensão e expressão ${ }^{1}$ das duas línguas e à estrutura simultânea da organização dos elementos da língua de sinais.

Aprender Libras para os ouvintes significa aprender uma segunda língua. $\mathrm{Na}$ perspectiva comunicativa, ensinar uma língua é trabalhar com o desenvolvimento da competência comunicativa com o componente linguístico ativado pelas vivências do

\footnotetext{
"Mestre em Linguagem e Ensino da Universidade Federal de Campina Grande. Professora da Libras da Unidade Acadêmica de Letras da UFCG. E-mail: girlainefca@ gmail.com

${ }^{* *}$ Professora titular do Programa de Pós-Graduação em Linguagem e Ensino da Universidade Federal de Campina Grande. Participa do grupo de pesquisa Teorias da Linguagem e Ensino. E-mail: augusta.reinaldo@gmail.com

*** Professora do Programa de Pós-graduação em Linguagem e Ensino e do Curso de Letras Libras na Universidade Federal de Campina Grande. Membro do Grupo de Pesquisa Abordagens do Texto Literário na Escola. E-mail: sbportoneves@gmail.com.

${ }^{1}$ As línguas de sinais são línguas de modalidade visual-espacial.
} 
uso real e significativo da língua alvo, realizada na interação. Essa perspectiva de ensino de língua se diferencia, em termos de objetivo, da perspectiva centrada na gramática, em que o objetivo central é transmitir conteúdo da estrutura gramatical da língua alvo. (GESSER, 2010).

A importância da introdução da perspectiva comunicativa nos cursos de línguas foi salientada por Almeida Filho (1998 apud GESSER, 2010, p. 22), nos seguintes termos:

\begin{abstract}
A abordagem comunicativa começava a dar um tom mais humanista, focado em um processo mais interativo para o ensino da língua. Assim, os cursos de línguas foram desenvolvidos e neles a língua não era mais focada em descrições de conceitos gramaticais ou lexicais, e sim em sistemas de significados necessários para o uso comunicativo.
\end{abstract}

Nessa perspectiva, todo texto é produzido em uma dada situação de interação, envolvendo ações e práticas de linguagem, portanto, atos comunicativos.

Adotamos essa perspectiva para o ensino e aprendizagem de Libras como segunda língua para ouvintes (L2), tomando o interacionismo sociodiscursivo (ISD) como base teórica e elegendo um gênero textual em Libras como forma de apresentar e refletir sobre como essa língua se constitui na sociedade.

Considerando que o ISD, em sua essência, é pouco estudado no Brasil na área de ensino de Libras, interessa-nos contribuir com esse conhecimento, focalizando, na pesquisa sobre a Libras, a construção de saberes desse enfoque teórico e sua exploração aplicada, de forma a possibilitar uma alteração na realidade de ensino da Libras como L2 para ouvintes.

Este artigo, que faz parte de uma pesquisa em andamento, procura alinhar-se aos estudos voltados para o ensino dos gêneros formais em contexto escolar. Entendemos, com Dolz e Schneuwly (2004), que a abordagem do ensino dos gêneros falados (em Libras, sinalizados) na escola não visa a ensinar gêneros informais do cotidiano, nem a enquadrar a fala/sinalização dos usuários/interlocutores em prescrições normativas sem considerar as situações comunicativas reais.

Para isso os estudos interacionistas sociodiscursivos defendem a construção do modelo didático de um gênero como etapa deve anteceder uma intervenção didática com vistas ao desenvolvimento de capacidades de linguagem do aprendiz.

Alinhando-se a essa perspectiva, o estudo aqui apresentado pretende: (1) identificar as características definidoras do gênero instrução de percurso; e (2) apontar e descrever dimensões relevantes desse gênero para o ensino de Libras como L2.

O artigo está constituído de quatro seções: a primeira, introdução, problematiza o tema e define os objetivos do trabalho; a segunda fundamenta teoricamente o estudo na perspectiva do Interacionismo Sociodiscursivo sobre o modelo de análise de texto e sobre o modelo didático de gênero; a terceira descreve os aspectos metodológicos do estudo quanto ao contexto de ensino em foco - Libras como L2 para graduando ouvintes de Letras - Língua Portuguesa e Letras - Língua Inglesa, e quanto aos procedimentos de coleta e de geração dos dados para análise; a quarta parte identifica e descreve as dimensões do gênero instrução de percurso consideradas relevantes para o ensino desse gênero. Seguem-se as considerações finais e as referências. 
1.Interacionismo sociodiscursivo (ISD): modelo analítico e modelo didático de gênero

Neste estudo, seguimos orientações teórico-metodológicas oriundas do interacionismo sociodiscursivo (ISD), em dois dos seus campos de atuação: o da conceituação e análise da linguagem humana, materializada em gêneros textuais, com o modelo de análise de gênero; e o da didática de língua, com o conceito de modelo didático de gênero como ferramenta para o ensino de língua centrado em gênero textual.

Modelo organizacional enunciativo

Em relação ao primeiro campo, o ISD entende as condutas humanas como "ações situadas cujas propriedades estruturais e funcionais são, antes de tudo, um produto da socialização" (BRONCKART, 1999, p.13). Assim, as ações verbais são compreendidas como mediadoras e constitutivas do social, em que interagem múltiplos e diversos interesses, valores, conceitos, teorias, objetivos e significações de si e dos outros: "a ação constitui o resultado da apropriação, pelo organismo humano, das propriedades da atividade social mediada pela linguagem" $(1999, \mathrm{p} .42)$.

Nesse sentido, os gêneros textuais são resultado da linguagem em funcionamento nos grupos humanos, isto é, do agir comunicativo, que é constitutivamente social e delimitador das ações dos agentes particulares, em sua singularidade humana e no conjunto de suas capacidades psicológicas. (BRONCKART, 1999). Ou seja, as possibilidades de ações de linguagem se traduzam nos vários gêneros utilizados na sociedade, pois quando uma ação de linguagem é realizada, um texto é produzido, a partir dos conhecimentos que são necessariamente uma reestruturação das representações do seu agente produtor, manifestadas em discurso/texto de modo empírico.

Como decorrência desse modo de conceber a linguagem, os gêneros e os textos, o modelo de produção e análise de gênero, proposto por Bronckart (1999, 2008), envolve um olhar sobre as relações de interdependência entre os mundos representados, a situação de produção do texto e a arquitetura interna do texto. De acordo com os posicionamentos teóricos assumidos pelo autor nessas duas publicações, esse modelo pode ser compreendido numa perspectiva descendente que envolve diversos níveis de análise, desde o mais abrangente até o mais específico, conforme apresentados a seguir.

As condições de produção dos textos

O primeiro nível de análise está representado pelo conjunto dos parâmetros envolvidos na situação de ação de linguagem experimentada pelo agente, pelos processos de tomada de empréstimo ao intertexto do modelo do texto empírico. Essa situação de ação de linguagem define-se a partir das propriedades dos mundos formais (físico, social, subjetivo), que podem influenciar a produção textual. Trata-se de conjuntos de representações sociais e de representação particular que se manifestam em três situações: a situação de ação de linguagem externa, composta pelas "características 
dos mundos formais, como uma comunidade de observados poderia descrever"; a situação de ação de linguagem interna e/ou efetiva, advinda das "representações sociais sobre esses mesmos mundos"; e, por fim, a situação de ação interiorizada, que é a "subjetividade realmente sobre a produção de texto empírico". (BRONCKART,1999, p. 91-92).

O contexto da produção constitui um componente importante relativo à situação de interação/comunicação em que o locutor/produtor se encontra. Considera-se nesse nível o conjunto dos parâmetros que podem influenciar a forma como o locutor/produtor organizará seu texto. Os fatores do contexto de produção se dividem em dois conjuntos: o primeiro refere-se ao mundo físico; o segundo, ao mundo social e subjetivo.

No primeiro, todo texto resulta de um comportamento verbal concreto, o contexto "físico" ( situado entre espaço e tempo) por quatro parâmetros:

(1) Lugar de produção: o lugar físico em que o texto é produzido;

(2) Momento de produção: a extensão do tempo durante a qual o texto é produzido;

(3) Emissor: a pessoa que produz fisicamente o texto, podendo essa produção ser efetuada na modalidade oral ou escrita;

(4) Receptor: a(s) pessoa(s) que pode(m) perceber concretamente o texto. (p.93)

$A$ produção oral $^{2}$ advinda desse contexto de produção acontece quando o receptor está, geralmente, situado no mesmo espaço-tempo do emissor e este pode responder-lhe.

No segundo contexto, todo texto deve se inscrever nas atividades de formação social como uma forma de interação comunicativa do mundo social (normas, valores, regras etc), e do mundo subjetivo (imagem que o agente tem de si ao agir). Esse contexto sociosubjetivo também pode ser agrupado em quatro parâmetros principais.

(1) Lugar social: qual formação social, qual instituição ou, de forma mais geral, em que modo de interação o texto é produzido: escola, família, mídia, exército, interação comercial, interação informal, etc.

(2) Posição social do emissor (enunciador): qual é o papel social que o emissor desempenho na interação em curso - papel de professor, de pai, de cliente, de superior hierárquico, de amigo, etc.?

(3) Posição social do receptor (destinatário): qual é o papel social ao receptor do texto papel de aluno, de criança, de colega, de amigo etc.?

(4) Objetivo(os) da interação: qual é, do ponto de vista do enunciador, o(os) efeito(os) que o texto pode produzir no destinatário? (p.94)

Importante observar a clara distinção entre o estatuto de emissor/receptor (indivíduo que produz ou recebe um texto) e o de enunciador/destinatário (papel social assumido, respectivamente, pelo emissor e pelo receptor). Outra observação importante, em termos de terminologia, é que Bronckart prefere a expressão agente-produtor ou, de forma mais simplificada, o termo autor (1999, p.97).

\footnotetext{
${ }^{2}$ No tocante à interação face a face, utilizamos o terno "oral" advindo dos referenciais teóricos por nós adotados, mas estamos considerando como "oral" a produção sinalizada.
} 
Arquitetura textual

Nível que envolve as propriedades linguísticas, discursivas e enunciativas que fazem parte da organização estrutural do texto, também denominada de folhado textual. Três camadas estão intimamente interligadas nessa organização: infraestrutura geral do texto, mecanismos de textualização e mecanismos de responsabilização enunciativa.

A infraestrutura geral do texto

Camada textual de nível profundo, constituída por dois regimes de organização: o da planificação geral do conteúdo temático e o dos tipos de discurso, os quais têm em seu interior os tipos de sequência. (BRONCKART, 2008, p.89).

A planificação geral do conteúdo temático é a forma como esse conteúdo é organizado. Essa organização é cognitiva, e o produtor organiza o conteúdo de acordo com o conhecimento que tem sobre o tema e, sobretudo, sobre os mundos discursivos e os parâmetros gerais do eixo do Expor e do Narrar. Essas coordenadas gerais se configuram nos tipos discursivos, podendo o plano global de um texto "assumir formas extremamente variadas": cada texto tem suas especificidades que se vinculam às especificidades de um dado gênero, como tamanho, conteúdo temático, condições externas à produção (suporte, variante oral-escrito), forma como se articulam no texto os tipos de discurso e os tipos de sequências (BRONCKART 1999).

O plano geral de um texto é descrito na forma de um resumo do conteúdo temático, abstraindo a maior parte das formas de estruturação interna do texto, segundo os tipos de sequências (BRONCKART, 1999, p.248): narrativa, descritiva, argumentativa, explicativa. Em um dado texto haverá a presença predominante de uma delas, podendo haver em seu interior diferentes tipos sequenciais.

O segundo regime de organização do texto, neste primeiro nível de análise da arquitetura textual (infraestrutura) são os tipos de discursos: "segmentos de texto que se caracterizam pela mobilização de subconjuntos particulares de recursos linguísticos e que revelam a construção de um determinado discursivo" (BRONCKART, 2008, p.89). Esses mundos são "formatos organizadores das relações entre as coordenadas da situação de ação de um actante e as coordenadas dos mundos coletivamente construídos na textualidade" (BRONCKART, 2008, p.91). Os tipos de discurso apresentam marcas que os identificam (BRONCKART,1999; p.158-175).

Aplicando essa noção ao texto instrucional utilizado neste estudo para exemplificar os tipos de discurso na constituição do plano global, identifica-se nele o predomínio do discurso expositivo; os interactantes da ação verbal se encontram em conjunção com o tempo de produção e em implicação com conteúdo exposto.

No interior dos tipos de discurso encontra-se o terceiro elemento de análise da arquitetura - a sequência textual: modo de planificação do conteúdo temático, já organizado na memória do produtor na forma de macroestrutura (BRONCKART, 2008, p.89; BRONCKART,1999, p.234). Em sua abordagem sobre os tipos de sequências, Bronckart retoma Adam (1992), e distribui as sequências em relação aos tipos de discurso: as sequências narrativas mais ligadas aos relatos interativos e às narrações; as sequências argumentativas, explicativas e injuntivas, aos discursos teóricos e interativos; as dialogais, aos discursos interativos dialogados e as sequências descritivas, a todos os tipos de discurso (BRONCKART, 1999, p. 252). 
Nosso interesse se volta para a sequência injuntiva, segmento de texto em que o produtor visa a fazer o destinatário agir de algum modo ou em uma certa direção, ou seja, pretende alcançar um determinado efeito, ou persuadir seu destinatário a realizar alguma ação. Apresenta em sua textualização uma sucessão de ações instrucionais, realizadas pela presença de formas verbais no imperativo ou no infinitivo. Outro traço é a ausência de estruturação espacial ou hierárquica (BRONCKART,1999).

Estudos em Língua Portuguesa (ROSA, 2003; BALTAR, 2007; CAVALCANTE, 2016) têm demonstrado que a ação de instruir leva o agente produtor a criar no interlocutor um efeito de sentido que o faça agir de certo modo, seguindo um objetivo estabelecido pelo agente para o cumprimento de uma tarefa que produza um resultado. Para isso, o agente deixa pistas da opção da organização do texto, recorrendo, predominantemente, "as unidades linguísticas potencializadoras, do agir, como verbos de ação, observando um encadeamento preciso para que o resultado da ação seja exitoso" (BALTAR, 2007, P. 158)

Nesta perspectiva, na utilização da sequência injuntiva, ao desejar fazer o seu destinatário agir, o enunciador do texto explicita o "como fazer", através da sua ação linguística dividida em partes: ação principal - macroobjetivo acional a se executar; ações secundárias - apresentação pelo enunciador de uma série de comandos; macroobjetivo atingido - plano de execução. De acordo com Rosa (2003. p. 33), o plano geral da sequência injuntiva se caracteriza por um protótipo composto por três fases básicas de macroproposições:

$1^{\text {a }}$ fase: exposição do macroobjetivo acional:

indicação de um objetivo geral que se deve atingir sob a orientação de um plano de comandos;

$2^{a}$ fase: apresentação dos comandos:

disposição de uma sequência de ações (coordenadas ou não) a ser executada para que se possa atingir o macroobjetivo acional; e

$3^{\mathrm{a}}$ fase: justificativa:

esclarecimento, por parte do produtor do texto, em face da situação de ação, sobre os motivos pelos quais seu destinatário deve seguir o(s) comando(s) estabelecido(s).

A $1^{\mathrm{a}}$ fase apresenta o objetivo pretendido. A $2^{\mathrm{a}}$ fase consta da apresentação dos comandos que constituem uma ordem de ações compostas por uma sequência injuntiva orientando o gênero. A $3^{\text {a }}$ fase é constituída pela justificativa; por resultar da decisão do produtor, sua aparição é mais restrita, pois sua função é deixar o destinatário esclarecido dos motivos para seguir os comandos que foram estabelecidos pelo enunciador. Assim, do ponto de vista funcional, o plano virtual de instrução apresentado pelo enunciador será concluído com êxito se o destinatário executar como esperado por aquele.

Rosa (2003), seguindo a perspectiva tipológica de texto de Adam (2001), reflete sobre as funções sociocomunicativas dos textos injuntivos, em três categorias: (a) textos instrucionais-programadores; (b) textos de conselhos; e (c) textos reguladoresprescritivos.

Trazendo a contribuição de Adam para a perspectiva do gênero de Bronckart, entendemos que as sequências da instrução de percurso sinalizadas na situação de ensino enfocada no presente estudo se configuram como segmentos de "textos instrucionais-programadores, já que visam a instruir/ensinar alguém a fazer algo" (ROSA, 2003. p. 31). 
Enfim, a forma comunicativa assumida pela sequência injuntiva é a da orientação procedimental para se conseguir um determinado objetivo (CAVALCANTE, 2016, p. 73-74).

\section{Mecanismos de textualização}

Os mecanismos de textualização representam o nível intermediário do modelo de análise textual proposto por Bronckart $(1999 ; 2008)$, e envolvem três conjuntos de mecanismos responsáveis pela coerência temática no plano da textualização:

a) conexão: representados por organizadores textuais que marcam as articulações da progressão temática. Esses organizadores podem ser classificados pelo valor semântico: "alguns organizadores têm valor mais temporal (depois, súbito, antes que); outros, um valor mais 'lógico' (de um lado, ao contrário, porque); outros ainda, um valor espacial" (no alto, desse lado, mais longe). (BRONCKART, 1999; p. 267). Esses organizadores desempenham papel relevante na textualização das instruções de percurso, como será demonstrado na seção 4.

b) coesão nominal: constituídos por sintagmas nominais ou por pronomes que marcam as relações de dependências existentes entre argumentos que têm as mesmas propriedades referenciais, assumindo uma função sintática de sujeito ou objeto. Sua função no texto é introduzir uma unidade significativa, um elemento novo, ou realizar uma retomada, por meio de duas categorias de marcação: anáforas pronominais (pronomes pessoais, relativos, possessivos demonstrativos e reflexivos), encontradas, mais frequentes nos discursos da ordem do Narrar; e as anáforas nominais (sintagmas nominais de diversos tipos), encontradas com maior frequência em discursos da ordem do Expor. (BRONCKART, 1999; p. 267).

c) coesão verbal: constituídos pelos verbos e seus determinantes - os tempos verbais - que, em seu conjunto, assumem valores gerais de significado (temporalidade, aspectualidade, modalidade); valores mais específicos (simultaneidade, anterioridade); valores aspectuais (realizado, imperfectivo, frequentativo); valores modais de asserção (modalidade assertiva), de hipótese (modalidade lógica). As escolhas verbais são realizadas levando em consideração três parâmetros: o momento da produção, o momento do processo e o momento psicológico de referência. Em sua relação com os tipos de discurso, é a temporalidade o aspecto principal, pois é ela que registrará o caráter conjunto e disjunto presente no eixo do expor e do narrar. (BRONCKART, 1999, p.273).

Como a finalidade do uso desses mecanismos é assegurar a coerência temática, são distribuídos nos textos e, geralmente, marcam as articulações entre os tipos de discurso e os tipos de sequências.

\section{Mecanismos de responsabilização enunciativa}

Assim renomeados por Bronckart (2008, p.90) ${ }^{3}$, esses mecanismos garantem a manutenção da coerência pragmática ou interação como texto, esclarecendo os posicionamentos enunciativos (Quais são as instâncias que assumem o que é enunciado

\footnotetext{
${ }^{3}$ Denominados de mecanismos enunciativos em Bronckart (1999, p.319).
} 
no texto? Quais são as vozes que aí se expressam?). Tais posicionamentos traduzem, por meio das vozes e das modalizações, as diversas avaliações (julgamentos, opiniões, sentimentos) sobre alguns aspectos do conteúdo temático (BRONCKART,1999, p. 130). São qualificados como superficiais por operarem quase independentemente da progressão do conteúdo temático, por isso estão menos presentes que os mecanismos de textualização. A principal função desses mecanismos é orientar a interpretação do destinatário (BRONCKART, 2008, p.90).

Enfim, o modelo bronckartiano de produção e análise de textos, de natureza descendente, tem sido utilizado pelos estudiosos do ISD nas situações de leituras e interpretações de dados, como também na análise de gêneros e elaboração de material didático. Tendo surgido da preocupação com o ensino de língua, esse modelo gerou um instrumento didático para o ensino centrado no gênero, aprofundando e ampliando o quadro de pesquisas do ISD.

No item a seguir, procuramos explicar essa utilização do modelo de análise pelos pesquisadores de Genebra, como também por pesquisadores brasileiros, para a construção de modelo didático de um gênero, a partir da identificação e descrição das suas dimensões relevantes para o ensino.

\section{Modelo didático de gênero}

Os pesquisadores do campo didático do ISD, em particular da didática de línguas, defendem que, para que os objetivos de ensino-aprendizagem de gêneros possam ser alcançados, as práticas escolares devem ser orientadas pelo que denominam de modelo didático do gênero (MDG) a ser ensinado, ou seja, por "um objeto descritivo e operacional, construído para aprender o fenômeno complexo da aprendizagem de um gênero" (DE PIETRO \& SCHNEUWLY ([2003] 2009, p. 39).

A construção desse modelo envolve a descrição das dimensões constitutivas do gênero e a seleção daquelas consideradas importantes para seu ensino, bem como daquelas necessárias para um determinado nível de ensino. Ainda de acordo com esses autores, nessa construção pode-se utilizar de referências teóricas diversas sobre o gênero a ser ensinado, além de referências obtidas pela observação e análise de práticas sociais que envolvem o gênero em questão, junto a especialistas na sua produção.

Seguindo esses autores, muitos pesquisadores brasileiros têm adotado, na construção do MDG, as categorias de análise do modelo bronckartiano (cf. item 2.1) para descrever um conjunto de textos pertencentes ao gênero selecionado. Destacamos aqui as contribuições de Machado e Cristovão (2006), Silva (2009) e Carnin \& Almeida (2015), que, observando a perspectiva descendente desse modelo, consideram os seguintes elementos (dimensões) constitutivos de um gênero:

a) as características da situação de produção (quem é o emissor, em que papel social se encontra, a quem se dirige, em que papel se encontra o receptor em que local é produzido, em que instituição social se produz e circula, em que momento, em qual suporte, com qual objetivo, em que tipo de linguagem, qual a atividade não verbal a que se relaciona, qual o valor social lhe é atribuído etc.);

b) os conteúdos típicos do gênero.

c) as formas de mobilizar esses conteúdos;

d) a construção composicional característica do gênero, ou seja, o plano global mais comum que organiza seus conteúdos; 
e) o seu estilo particular, ou seja:

- as configurações específicas de unidades de linguagem que se constituem como traços da posição enunciativa do enunciador (presença/ausência de pronomes pessoais de primeira e segunda pessoa, dêiticos, tempos verbais modalizadores, inserção de vozes);

-as sequências textuais e os tipos de discurso predominantes e subordinados que caracterizam o gênero;

- as características dos mecanismos de coesão nominal e verbal;

-as características dos mecanismos de conexão;

-as características dos períodos;

- as características lexicais.

(MACHADO \& CRISTOVAO, p.557-558; SILVA, p.141-154; CARNIN \& ALMEIDA, p. 36-38)

Em relação a essas categorias de análise, esses autores chamam a atenção para que todos os níveis textuais elencados sejam vistos em seu valor dialógico, como traços do agir do produtor e das restrições do gênero relativas ao quadro de realização das atividades e das interações.

Retomando a posição de De Pietro e Schneuwly, Machado e Cristovão, bem como Carnin \& Almeida, lembram que as categorias de análise podem ser orientadas por conceitos de outras teorias, quando compatíveis, podendo ainda ser criados novos conceitos quando necessário. Enfatizam a importância da base teórica para as adaptações necessárias em cada contexto de ensino, destacando que o modelo didático também permite, para um mesmo público-alvo, construir atividades de ensino/aprendizagem diversas.

Nesse sentido, são pontos relevantes para a construção de um modelo didático do gênero: conhecer o estado da arte dos estudos sobre o gênero em estudo, conhecer as capacidades dos discentes e prever suas dificuldades ao se depararem com textos pertencentes ao gênero selecionado. Além disso, faz-se necessário ter experiências de ensino/aprendizagem desse gênero.

Esses pontos ajudam o professor a definir o tipo de intervenção didática a ser desenvolvida e a construir o modelo, com a adaptação dos objetivos de ensino ao nível dos alunos e a organização das categorias a serem exploradas em uma determinada sequência de atividades.

O objetivo maior é a realização do projeto de apropriação das dimensões selecionadas do gênero, conforme o nível dos aprendizes. Por fim, como em todo processo de avaliação formativa, as atividades desenvolvidas podem exigir um retorno ao modelo didático para sua modificação no que se fizer necessário, num processo contínuo de transformação desse instrumento de avaliação/produção de materiais didáticos baseados em gênero. (MACHADO e CRISTOVÃO, 2006, p. 558-559).

\section{Aspectos metodológicos}

Este estudo faz parte de uma pesquisa-ação de caráter exploratório, cujo contexto de construção do objeto de ensino foi o de um curso de extensão no âmbito de um projeto de formação de professores de Libras como $\mathrm{L}_{2}^{4}$, vinculado à Unidade Acadêmica de Letras da Universidade Federal de Campina Grande (UFCG) - Paraíba.

${ }^{4}$ Trata-se do projeto "Formação de professores de Libras como primeira e segunda língua" (PROBEX/UFCG2016 e 2017), do qual surgiu o projeto de pesquisa "Ensino de Libras para aprendizes 
A coleta e geração dos dados foi realizada na disciplina Libras (L2) ministrada pela primeira autora (surda) para alunos ouvintes de graduação de Letras - Língua Portuguesa e Língua Inglesa.

O vídeo constituiu o recurso didático para ensinar a sinalização na atividade de instruir como os graduandos deveriam realizar determinado percurso, sinalizado em um mapa do campus universitário.

Os dados selecionados para análise estão representados pela instrução de percurso que teve o prédio da Reitoria como ponto de partida e o do Banco Brasil como ponto de chegada (REITORIA $\rightarrow$ BB).

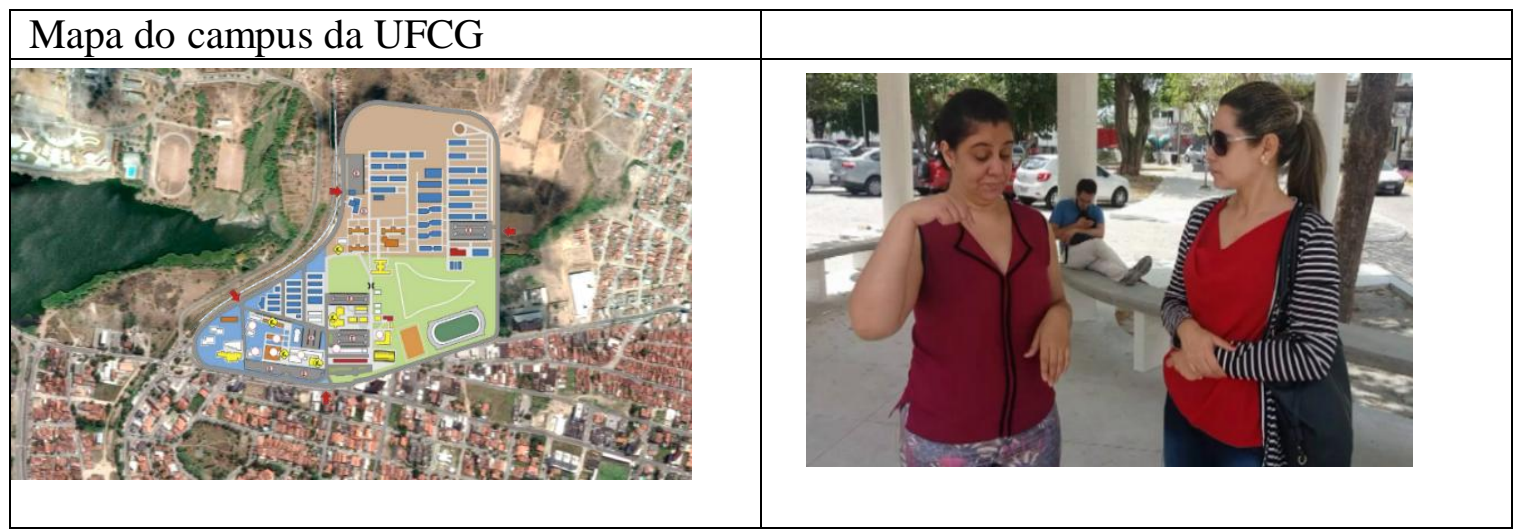

Fonte: dados da pesquisa, 2019

A transcrição dos dados videogravados foi feita com a ajuda do programa ELAN (EUDICO language Annotator).

Criado pelo Instituto Max Planck de Psicolinguística (Nijmegen, na Holanda), e usado para análises linguísticas diversas, o ELAN permite sincronizar as imagens em vídeo como anotações, para os registros dos diferentes elementos que compõem um texto: linguagem verbal e gestos, ou sinalizações (sinais manuais e sinais não-manuais), pois ele converte os arquivos em vídeo em arquivos de word, compatível com esse software.

Nesse contexto, a Libras textualiza a informação para quem solicitou a informação, iniciando pelo ponto de partida, registrando a incorporação do parâmetro localização articulado com o movimento do tronco e das mãos e com a direção do olhar dos sinalizadores em direção ao ponto de chegada.

\section{Identificação e descrição das características da instrução de percurso em libras}

A observação de um exemplar de instrução de percurso, sinalizado pela professora-pesquisadora para os graduandos ouvintes, mostra duas dimensões constitutivas desse gênero como relevantes para seu ensino e aprendizagem pelo público-alvo, alunos ouvintes de Letras - Língua Portuguesa e Letras - Língua Inglesa: a organização sequencial, que se manifesta recorrentemente pela sequência injuntiva; e os mecanismos de textualização, que se manifestam prioritariamente com a marcação

ouvintes: a injunção e o espaço como dimensões ensináveis do gênero instrução de percurso", submetido e aprovado pelo Conselho de Ética, parecer no 3.229.121. 
das unidades linguísticas da espacialização e localização. Não foram registradas nos dados ocorrências dos mecanismos enunciativos.

Nas subseções a seguir, são identificados e descritos os traços constitutivos das sinalizações prototípicas dessas duas dimensões do gênero em estudo.

\section{Organização sequencial injuntiva e os verbos direcionais}

A organização sequencial é a dimensão constitutiva da construção composicional, traduzida no plano global mais comum de organização dos conteúdos de um gênero. Nos dados selecionados essa dimensão está prototipicamente representada pela sequência injuntiva, marcada do ponto de vista linguístico pela presença das formas verbais imperativa e infinitiva.

No exemplo 1, a seguir observamos como a língua de sinais de texto na sequência injuntiva (ANDAR e VIRAR) dá possibilidade a contexto de instrução de percurso em ordem.

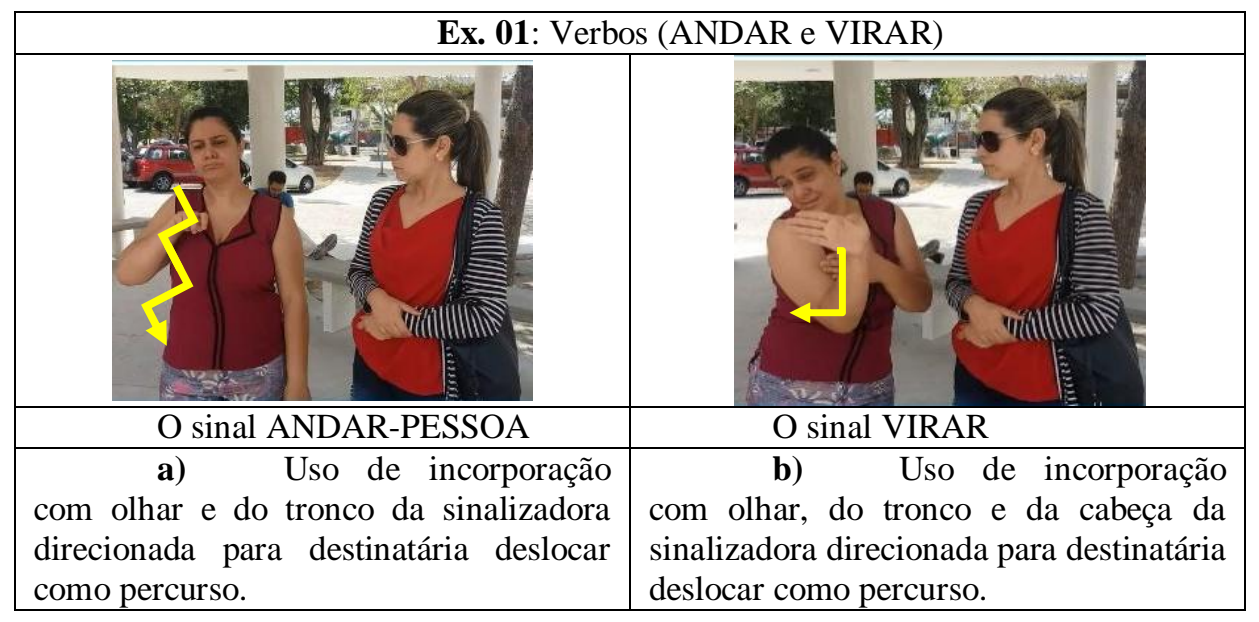

No exemplo 01, acima, podemos ver que a sinalizadora apresenta objetos (edificações de várias ordens: prédios e lombadas) e locais espaciais (virar à direita) que compõem uma cena da instrução de percurso. A observação atenta nos apresenta uma língua que funciona a partir da simultaneidade da produção da informação, pois a sinalizadora ensina o percurso utilizando o olhar, as mãos e o corpo que se deslocam pelo espaço de sinalização, ora realizando sinais manuais e corporais, ora marcando os pontos no espaço para esses objetos e locais. Em outras palavras, essa agente produtora visa fazer a destinatária agir na direção certa.

A língua de sinais na sequência injuntiva (verbo no infinitivo/imperativo: ANDAR-IR e VIRAR) dá possibilidade ao contexto de instrução de percurso em ordem. Direcionando nosso olhar para utilização da sequência injuntiva, ao desejar "fazer agir" sua destinatária, a autora explicita através da sua ação linguística o "como fazer" divididas em: ação principal - macroobjetivo acional a se executar; ações secundárias apresentação de uma série de comandos; macroobjetivo atingido - plano de execução formulado foi alcançado pela interlocutora.

Assim é possível identificar na instrução percurso para o Banco do Brasil o macroobjetivo acional - indicar o percurso até o banco. Para que a interlocutora 
entenda a marcação do percurso, deve seguir o plano de comandos explicitado verbalmente, desenvolvendo, assim, uma série de microações referentes ao processamento dos caminhos/percursos para, após a transformação da situação inicial, chegar ao produto final - encontrar o banco.

Nesse contexto, refletindo sobre a sequência injuntiva, identificamos que a Libras possui modos de produção textual para circulação na vida cotidiana social, textos de natureza instrucional relacionados com os objetivos comunicativos, como "fazer agir", que se constituem por uma organização textual e um funcionamento enunciativo planificado pela injunção.

4.1 Os organizadores da espacialidade e da localização e os sinais de apontação

Os organizadores textuais constituem a dimensão da textualização que se manifesta pela dêixis de espaço e de pessoa.

A observação dos dados da instrução de percurso selecionada permite-nos verificar que na Libras essa dimensão constitutiva desse gênero se materializa nos sinais de apontação, expressos por meio das seguintes unidades linguísticas: verbos direcionais (sIRo), pronomes demonstrativos (EST@, ESS@) e advérbios (LÁ, ALI) associados à direção do olhar e seu movimento; locais (REITORIA, UAED, ESTACIONAMENTOS, RU, BB).

Em algumas imagens capturadas, vemos que o uso de apontação (indicar) como gesto é o elemento mais utilizado na instrução de percurso selecionada. A característica geral da apontação é que ela está entre as categorias de organização linguística dos advérbios de lugar; pronomes pessoais e demonstrativos; localizações; dêixis e anáforas. São significados os referentes (pessoa e espaço).

No exemplo 02, abaixo, a apontação (pronome/dêixis) em segunda pessoa ( $2^{\mathrm{a}}$ TU/VOCÊ) indica a localização particular a ser tomada como referência para a realização do percurso.

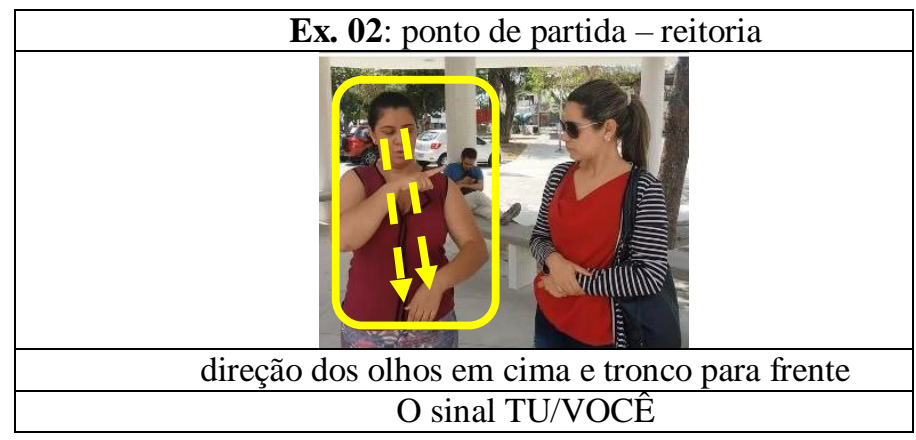

No espaço para a comunicação, uma pessoa que está buscando a compreensão assiste à sinalização de Libras precisa ficar atenta para a visualização das informações no espaço como sentido (direita ou esquerda), estes posicionamentos sempre estão sob a perspectiva do emissor da mensagem/ordem, como uma imagem no espalho.

Quanto ao local, este pode ser referente a vários aspectos da espacialidade. No exemplo 03, a sinalizadora direciona a cabeça e os olhos (e talvez tronco) em direção a uma localização. Essa imagem particular acontece simultaneamente com 
o sinal de um substantivo ou com a apontação para o substantivo. (QUADROS \& KARNOPP, 2004).

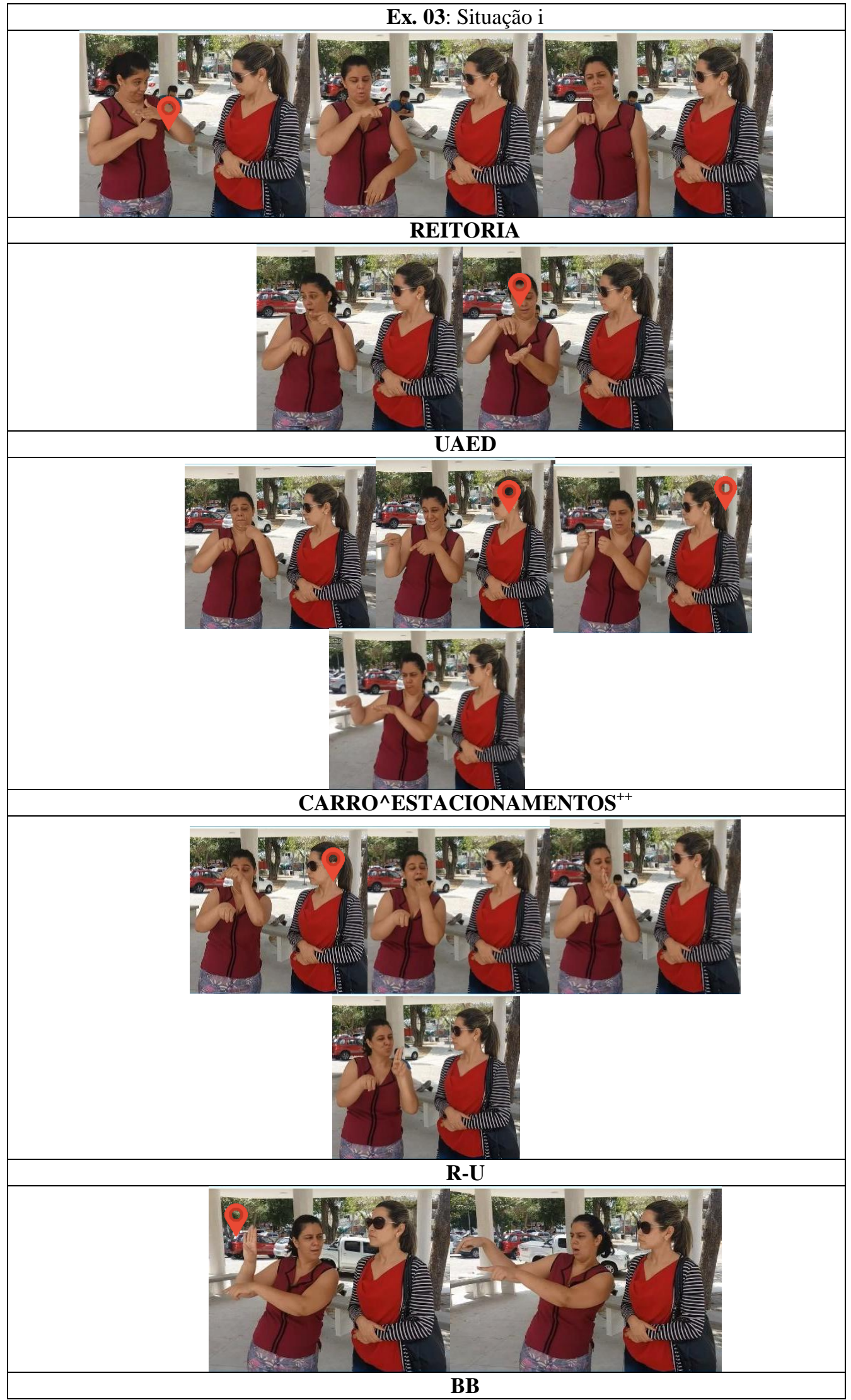


A ação em um espaço, ao ser de fato realizada, materializa no movimento as possibilidades da informação. Vejamos a cena da instrução original: as imagens com locais e objetos se interligam ao movimento do próprio corpo da sinalizadora. Assim nos trechos acima temos as partes de seu corpo expressamente voltadas para esse espaço, por exemplo, para direita, lado para o qual se deslocam as indicações dos locais: REITORIA, UAED, ESTACIONAMENTOS, R-U, B-B.

Nas comparações do verbo ANDAR são diferentes as configurações das mãos "5" e "G", que são classificadores, pois o andar se alterará dependendo de contextos, de pessoas presentes, como individual, que é o caso, e do espaço, para onde a pessoa vai. Assim, os verbos ANDAR, IR apresentam a sequência sinalizadora do verbo ANDARPESSOA mão em CM " 5 ”, que se apresenta diversas vezes incorporando o injuntivo e o gerúndio no mesmo sinal com a sinalização da instrução.

A descrição aqui apresentada mostra a instrução de percurso como um gênero da ordem do descrever/instruir, cujas dimensões relevantes para o ensino e consequente apropriação pelo aprendiz são: a) condição de produção (instrução de percurso por graduandos ouvintes no campus universitário); b) sequência injuntiva (verbo no infinitivo/imperativo: ANDAR-IR e VIRAR) e c) os organizadores textuais realizados por meio dos sinais de apontação das seguintes unidades linguísticas: verbos direcionais (sIRo), pronomes demonstrativos (EST@,ESS@) e advérbios (LÁ,ALI) associados à direção do olhar e seu movimento; locais (REITORIA, UAED, ESTACIONAMENTOS, RU, BB).

Portanto, essas são as características identificadas e descritas na análise de um exemplar do gênero instrução de percurso, sinalizado em uma situação de aula de Libras para graduando ouvintes de Letras. Os resultados dessa descrição apontam diretrizes para a elaboração de atividades didáticas diversas na intervenção em sala de aula.

\section{Considerações finais}

As reflexões apresentadas neste estudo objetivaram o levantamento e a análise das características definidoras da instrução de percurso no contexto de ensino de Libras para aprendizes, no nível A1. Os dados analisados nessa experiência apontam para a consideração de alguns pontos.

O primeiro é o de que o ensino da Libras na perspectiva do ISD constitui um espaço de desafios para alteração da realidade comunicativa de surdos e ouvintes na sala de aula, permitindo-nos ver que os conhecimentos teórico-metodológicos dos gêneros textuais favorecem a ampliação do material didático em Libras.

O segundo refere-se à necessidade de inserção, na pauta da formação dos docentes de Libras, do modelo de ensino centrado no gênero, contemplando desde as condições de produção, circulação e uso, passando pelo conteúdo temático e organização sequencial, até a textualização, via o uso das unidades linguísticas que necessariamente entram na configuração do gênero.

O terceiro e último ponto diz respeito ao fato de que os discentes ouvintes são apresentados a aprendizados de compreensão da Libras como L2 para a ampliação da percepção visual. Entendemos que, por mais prazeroso e estimulante que seja o aprendizado de uma segunda língua, a atividade da sinalização não é uma atividade de prática fácil. Ao docente cabe a responsabilidade de mostrar aos discentes a forma 
correta de sinalizar os movimentos do corpo, as expressões faciais etc, o que exige tempo, dedicação, esforço e, principalmente, abertura para conhecer novas formas de pensar o mundo e de se comunicar/interagir.

\section{Referências}

ADAM, J-M. Les discours procéduraux. In: GARCIA-DEBANC, Claudine. (Org.) Langages. Paris: Université de Lausanne. 2001, pp. 10-27.

ALMEIDA FILHO, J. C. P. Dimensões comunicativas no ensino de línguas. Campinas: Pontes, 1998.

BALTAR, Marcos. O conceito de tipos de discurso e sua relação com outras conceito do ISD. In: GUIMARÃES, A.M.M, MACHADO, A. R; COUTINHO, Antônia. (orgs). O Interacionismo Sociodiscursivo questões epistemológicas e metodológicas. Campinas: Mercado de Letras, 2007.

BRONCKART. J. P. Atividade de linguagem, textos e discursos: por um interacionismo sócio-discursivo. São Paulo: EDUC, 1999.

O agir nos discursos: das concepções teóricas às concepções dos trabalhadores: tradução Anna Rachel Machado, Maria de Lourdes Meirelles Matencio, Campinas, SP: Mercado de Letras, 2008.

CARNIN, Anderson; ALMEIDA, Alessandra Preussler de. Modelo(s) didático(s) de gênero: da concepção teórica à transposição didática na formação continuada de professores. IN: GUIMARÃES, Ana Maria de Mattos; CARNIN, Anderson; KERSCH, Dorotea Frank (ORGs). Caminhos da construção: reflexões sobre projetos didáticos de gênero. Campinas: Mercado das Letras, 2015.

CAVALCANTE, Mônica Magalhães. Os sentidos do texto. 1. Ed., $3^{\text {a }}$ reimpressão. São Paulo: Contexto, 2016.

DE PIETRO, J. F.; SCHNEUWLY, B. O modelo didático do gênero: um conceito da engenharia didática. Rev. Moara. Belém, n. 26, p. 15-52, ago/dez., [2003] 2009.

ELAN. Software desenvolvido pelo Max Planck Institute for Psycholinguistics. Disponível em: https://tla.mpi.n1/tools/tla-tools/elan/download/ Acessado em: 06/04/2019.

GESSER. Audrei. Metodologia de Ensino em LIBRAS como L2. Florianópolis: UFSC. Texto-base (Letras-Libras), 2010.

MACHADO, Anna Rachel; CRISTÓVÃO, Vera. A construção de modelos didáticos de gêneros: aportes e questionamentos para o ensino de gêneros. IN: Lilia Santos Abreu-Tardelli e Vera Lúcia Lopes Cristovão (ORGs). O ensino e a aprendizagem de gêneros textuais. Campinas: Mercado das Letras, 2006. 
QUADROS, R.; KARNOPP, L. Língua de Sinais Brasileira: estudos linguísticos. Porto Alegre: Artes Médicas, 2004.

ROSA, Adriana L. T. da. No comando, a sequência injuntiva! In: DIONISIO, Angela Paiva; BESERRA, Normanda as Silva [orgs]. Tecendo textos, construindo experiências. Rio de Janeiro: Lucerna, 2003.

SCHNEUWLY, Bernard e DOLZ, Joaquim. Gêneros orais e escritos na escola. Campinas (SP): Mercado de Letras; 2004.

SILVA, Carla Messias Ribeiro da. O modelo didático do Gênero comentário Jornalístico radiofônico: uma necessária etapa para a intervenção didática. Dissertação de Mestrado em Linguística Aplicada e Estudos da Linguagem: Pontifícia Universidade Católica de São Paulo PUC-SP. São Paulo, 2009.

Recebido em 22 de junho de 2019

Aceito em 08 de agosto de 2019 